Research Article

\title{
Impact of Cooperative Learning Approaches on Students' Academic Achievement and Laboratory Proficiency in Biology Subject in Selected Rural Schools, Ethiopia
}

\author{
Eyayu Molla ${ }^{1}$ and Meseret Muche $\mathbb{D}^{2}$ \\ ${ }^{1}$ Department of Biology, Bahir Dar University, Bahir Dar, Ethiopia \\ ${ }^{2}$ Department of Biology, Woldia University, Woldia, Ethiopia \\ Correspondence should be addressed to Meseret Muche; meseretmuche2009@gmail.com
}

Received 12 October 2017; Accepted 19 December 2017; Published 1 April 2018

Academic Editor: Gwo-Jen Hwang

Copyright (c) 2018 Eyayu Molla and Meseret Muche. This is an open access article distributed under the Creative Commons Attribution License, which permits unrestricted use, distribution, and reproduction in any medium, provided the original work is properly cited.

\begin{abstract}
The main objective of this study was to evaluate the impact of cooperative learning methods on students' academic achievement and laboratory proficiency in biology subject. Quasi-experimental control group interrupted time series design was employed. Data pertaining to these variables were collected from 369 students and 18 biology teachers in three schools. A series of biological tests and semistructured questionnaire were used to collect data. Multivariate analysis (two-way ANOVA) was used to analyze the test scores exposed by teaching methods, and semistructured questionnaire was administered to comprehend factors that hamper the successive execution of CL. Hence, multivariate analysis revealed that there was no significant $(P>0.05)$ difference in the pretest score of the learner academic performance; however, there were significant differences $(P<0.01)$ in the posttest results by teaching methods, but not by schools. Correspondingly, there were significant differences in the pretest $(P<0.05)$ and posttest $(P<0.01)$ results of the students' laboratory proficiency by teaching methods. The results exemplify that there was significant learning gain obtained via CLAD followed by cooperative discussion group (CDG). The result from the questionnaire survey showed that the number of students, lack of laboratory equipment, and so on hamper consecutive execution of CL.
\end{abstract}

\section{Introduction}

Education plays a pivotal role in maximizing individual's potentials and is a prerequisite for meaningful and sustained national economy [1]. Even though the educationists had made efforts in improving teaching-learning processes, instructional designers are still searching and experimenting to get best methods for optimal academic performance of the students [2]. This is because, in the traditional approach of teaching, most of the class time is spent by teachers talking and students watching and listening, and cooperative learning appears to be discouraged [3]. Similarly, Johnson et al. [4] elucidated that, in individual learning, how the students perceive and interact with one another is a neglected aspect of instruction. Correspondingly, the knowledge of biology contributes to scientific literacy and helps to understand the world in which we live [5,6]. However, the students' learning performance and achievement in biology have been poor over recent years [7]. The poor performance and laboratory proficiency in biology are influenced by not having expository approaches that stand up to challenge the objectives of biology education [5, 8-10]. Thus, schools should be encouraged to adopt pedagogical practices that promote the active involvement of students' learning [11]. One practice that has received widespread coverage over the past decades is cooperative, small-group learning [12]. This is a pedagogical practice that helps students to gain and create both academic and social relationships as well as to accomplish shared goals [13]. Through such kind of interaction, students learn to crossexamine issues, share ideas, elucidate differences, and 
construct new understandings [14]. Even though cooperative learning (CL) has revealed a number of integral functions, it has not been a far and broaden approach of teaching methodology in the study areas (Gassaye, Fert, and Kimer Dengay secondary schools). Correspondingly, research findings showed that very few teachers who implemented CL method could not even consider some aspects of the learners being organized on the basis of academic achievement, interest, and gender; these may in turn degrade and worsen the students' perception towards CL activities. Correspondingly, researches like [3, 15-18] were conducted on CL in mathematics, English, education, and sociology, and few studies were conducted on the effectiveness of CL in science education in some other African countries like Kenya and Nigeria [6, 7, 19]; however, there are no further studies which revealed the impact of CL in biology in Ethiopia, in particular in the study area. Therefore, the aim of this study was to assess the variation in the students' academic achievement and laboratory competency treated by the individual learning and heterogeneous and homogeneous CL approaches in grade nine students in biology subject in the selected rural schools in Farta District, South Gondar Zone, Northwest Ethiopia.

1.1. Research Questions. To achieve the central aim of the study, the following research questions were entertained in this study:

(1) To what extent cooperative learning (CL) strategies are effective to enhance students' academic achievement and laboratory proficiency in biology subject?

(2) What is the perception of teachers and students towards the impact of cooperative learning (CL) methods on students' academic achievement and laboratory proficiency?

\subsection{Hypothesis}

$\mathbf{H}_{\mathbf{1}}$ : there is no significant difference in the average test scores of academic achievement of the students exposed to different teaching methods by study areas.

$\mathbf{H}_{2}$ : there is no variation in the mean test scores of the students' laboratory proficiency as influenced by different teaching methods and study areas.

\section{Materials and Methods}

2.1. Research Design and Experimental and Control Groups of the Study. This study examined the impact of cooperative learning approaches on students' academic achievement and laboratory proficiency in grade nine students in selected rural schools. The research design employed to conduct this study was quasi-experimental control group interrupted time series design involving preobservation (pretest) and postobservation (posttests). In this design, two treatments were compared with two experimental groups. Accordingly, the students were randomly assigned to each of the teaching methods, namely, individual learning (IL) taken as the control group and the experimental groups (cooperative discussion group or CDG (one top achiever student leads the other five different academic performance levels of students) and cooperative learning achievement division (CLAD) based on the previous academic competency procured from the schools' registrar). As stated in [20-22], the cooperative learning regarding achievement division (CLAD) was the most successful teaching method in which students are organized based on their academic performance into top achievers, middle achievers, and lower achievers discretely. They further described that, through CLAD, students must be held individually accountable, and to achieve group objectives, the students pay their roles autonomously. Afterwards, a series of biological activities and tests were offered in the same way to those students engaged in each teaching method to evaluate their academic achievement and laboratory skill performance in biology. Moreover, to comprehend the teachers' and students' acuity on the impact of CL approaches, a semistructured questionnaire was administered in the selected rural schools in Farta District, Northwest Ethiopia.

2.2. Sampling Technique and Population Size. The studied groups of this study were grade nine students, and the sample size was determined using the following formula recommended by Kothari [23]:

$$
n=\frac{Z^{2} * P * q * N}{e^{2}(N-1)+Z^{2} * P * q},
$$

where $Z=1.96$ (95\%) confidence level, $P$ (estimated characteristic of the population $)=0.5, q=1-P, e=0.05$ of the accepted error, and $N=9940$. Subsequently, 369 students (123 students) for each of the three areas, namely, the Gassaye, Fert, and Kimer Dengay secondary schools, were selected to evaluate the academic achievement and laboratory competency as exposed to different teaching methods in the purposively selected rural schools in Farta District, South Gondar Zone, Northwest Ethiopia. Furthermore, eighteen biology teachers were purposively selected for the questionnaire survey of the study so as to assess their overall perception on the execution of the cooperative learning methods.

2.3. Data Analysis Techniques. The collected data were analyzed using generalized linear model of multivariate analysis (two-way ANOVA) using SPSS version 20. Furthermore, quantitative data obtained through semistructured questionnaire were analyzed using descriptive statistics to apprehend the perception of teachers and students on the successive execution of CL. 
TABLE 1: Multivariate analysis on students' academic achievement scores by teaching methods and areas.

\begin{tabular}{|c|c|c|c|c|c|c|c|c|c|c|}
\hline \multirow{2}{*}{ DV } & \multicolumn{5}{|c|}{ Study areas } & \multicolumn{5}{|c|}{ Method of teaching } \\
\hline & SS & DF & MS & $F$ & $P$ value & SS & DF & MS & $F$ & $P$ value \\
\hline Pretest & 33.3 & 2 & 16.7 & 0.2 & $0.8^{\text {ns }}$ & 365.2 & 2 & 182.6 & 1.8 & $0.2^{\mathrm{ns}}$ \\
\hline Posttest 1 & 848.4 & 2 & 424.2 & 2.2 & $0.1^{\mathrm{ns}}$ & 9612.9 & 2 & 4806.4 & 25.1 & $0.00^{*}$ \\
\hline Posttest 2 & 117.9 & 2 & 59 & 0.5 & $0.6^{\mathrm{ns}}$ & 10679.2 & 2 & 5339.6 & 44.2 & $0.00^{*}$ \\
\hline Posttest 3 & 110.7 & 2 & 55.4 & 0.3 & $0.7^{\mathrm{ns}}$ & 12721.9 & 2 & 6360.9 & 39.9 & $0.00^{*}$ \\
\hline
\end{tabular}

*Significant at $P<0.01 ;{ }^{* *}$ significant at $P<0.05$; ns, not significant at $P<0.05$; DV, dependent variable; SS, sum square; DF, degree of freedom; MS, mean square.

TABle 2: Post hoc analysis on students' academic achievement via successive test scores (mean \pm SD).

\begin{tabular}{|c|c|c|c|c|c|}
\hline \multirow{2}{*}{ Rural schools } & \multirow{2}{*}{ Teaching methods } & \multicolumn{4}{|c|}{ Test scores } \\
\hline & & Pretest & Posttest 1 & Posttest 2 & Posttest 3 \\
\hline \multirow[t]{3}{*}{ FG } & CLAD & $39.0 \pm 9.3$ & $63.7 \pm 13.7$ & $68.5 \pm 10.4$ & $72.0 \pm 10.5$ \\
\hline & IL & $41.6 \pm 10.4$ & $52.2 \pm 15.9$ & $59.5 \pm 11.2$ & $59.9 \pm 10.8$ \\
\hline & CDG & $38.6 \pm 8.5$ & $61.9 \pm 10.9$ & $63.4 \pm 9.2$ & $64.1 \pm 12.9$ \\
\hline \multirow[t]{3}{*}{ GG } & CLAD & $37.6 \pm 10.2$ & $67.0 \pm 16.3$ & $69.6 \pm 12$ & $73.0 \pm 16.2$ \\
\hline & IL & $41.8 \pm 9.4$ & $53.7 \pm 10.6$ & $54.4 \pm 9.8$ & $55.5 \pm 9.1$ \\
\hline & CDG & $37.8 \pm 11.6$ & $66.5 \pm 16.1$ & $71.2 \pm 12.1$ & $71.1 \pm 14.9$ \\
\hline \multirow[t]{3}{*}{ KG } & CLAD & $39.9 \pm 11$ & $66.4 \pm 12.9$ & $69.4 \pm 11.5$ & $69.8 \pm 13.3$ \\
\hline & IL & $39.2 \pm 10.2$ & $56.9 \pm 11$ & $57.2 \pm 10.9$ & $58.6 \pm 12.1$ \\
\hline & CDG & $39.6 \pm 10.5$ & $64.5 \pm 15.5$ & $68.3 \pm 11.3$ & $70.8 \pm 12.1$ \\
\hline LSD & & NS & $10.1^{*}$ & $10.5^{*}$ & $10.7^{*}$ \\
\hline
\end{tabular}

* Significant at $P<0.01$; NS, not significant; LSD, least significant difference; SD, standard deviation; IL, individual learning; CDG, cooperative discussion group; CLAD, cooperative learning achievement division; FG, Fert General Secondary School; GG, Gassaye General Secondary School; KD, Kimer Dengay General Secondary School.

\section{Results and Discussion}

\subsection{The Impact of CL on the Students' Academic Achievement in Biology Subject}

3.1.1. ANOVA on the Pretest Score of the Students Exposed to Different Teaching Methods by Areas. The two-way analysis of variance showed that there was no significant difference $(P>0.05)$ in the pretest scores of the students' academic achievement by teaching methods (IL, CDG, and CLAD) and study areas (Table 1). The numerical value obtained from most students' pretest result within the selected rural schools revealed that the students' biology result was below the average national grade point, in which relatively a bit higher test score was found in the students of Gassaye secondary school $(41.8 \pm 9.4)$, followed by Fert secondary school (41.6 \pm 10.4$)$ and Kimer Dengay secondary school $(39.9 \pm 11)$ (Table 2). This implied that the academic status of the learner was greatly comparable before exposing them to different teaching methods; this could be due to the teachers' knack to decide materials needed to conduct the lesson, academic and social-skill objectives, and the method of assigning students to groups. Accroding to Otuka and Uzoechi [9], the low academic achievement of the students' in biology could be attributed to the teachers devote much time on the individual learning method rather than in the innovative way of teaching. This result is also in line with the research findings reported by Gokkurt et al.
[16], which showed no significant difference between the achievements of the groups (CL and IL) according to the results of the independent $t$-test $(t(48=0.524 ; P>0.05))$ on the knowledge of GDC-IPPC in grade nine mathematics class. On the other hand, Muraya and Kimamo [7] found a statistically significant difference $(P<0.05)$ in achievement scores of students who had no prior knowledge (pretest) of the biology lesson.

3.1.2. Posttest Achievement Results of Students Exposed to Different Teaching Methods by Areas. The result of the two-way ANOVA revealed that there were significant $(P<0.01)$ differences in the posttest scores of the learner academic achievement through the influence of different teaching methods (Table 1). However, the learners' posttest achievement scores did not show significant difference $(P>0.05)$ by study schools. The students' exam result showed that there were trends in improving the academic performance evaluated through successive tests in contrast with the pretest result. This could be due to the methods of teaching delivered to the students transformed from the conventional lecturing method to the communicative way of teaching approach (CL). The highest mean value of the students' academic achievement posttest one $(67.0 \pm 16.3)$ in CLAD, posttest two $(71.2 \pm 12.1)$ in CDG, and post-test three $(73.1 \pm 16.2)$ in CLAD teaching methods was recorded in Gassaye and Fert secondary 
TABLE 3: Multivariate analysis on the students' laboratory proficiency by areas and teaching methods.

\begin{tabular}{|c|c|c|c|c|c|c|c|c|c|c|}
\hline \multirow{2}{*}{ DV } & \multicolumn{5}{|c|}{ Study areas } & \multicolumn{5}{|c|}{ Method of teaching } \\
\hline & SS & DF & MS & $F$ & Significance & SS & DF & MS & $F$ & Significance \\
\hline Pretest & 626.7 & 2 & 313.2 & 3.3 & $0.04^{* *}$ & 796.5 & 2 & 398.3 & 4.2 & $0.02^{* *}$ \\
\hline Posttest 1 & 289.2 & 2 & 144.6 & 0.6 & $0.6^{\mathrm{ns}}$ & 5264.7 & 2 & 2632.3 & 10.4 & $0.00^{*}$ \\
\hline Posttest 2 & 1146.2 & 2 & 573.1 & 2.9 & $0.5^{\mathrm{ns}}$ & 3992.4 & 2 & 1996.2 & 10.2 & $0.00^{*}$ \\
\hline Posttest 3 & 1527.5 & 2 & 763.7 & 4.1 & $0.02^{* *}$ & 4962.7 & 2 & 2481.3 & 13.4 & $0.00^{*}$ \\
\hline
\end{tabular}

*Significant at $P<0.01$; ** significant at $P<0.05$; ns, not significant at $P<0.05$; DV, dependent variable; SS, sum square; DF, degree of freedom; MS, mean square.

TABLE 4: Post hoc analysis on students' laboratory competency via successive test scores (mean \pm SD).

\begin{tabular}{|c|c|c|c|c|c|}
\hline \multirow{2}{*}{ Rural schools } & \multirow{2}{*}{ Teaching methods } & \multicolumn{4}{|c|}{ Test scores } \\
\hline & & Pretest & Posttest 1 & Posttest 2 & Posttest 3 \\
\hline \multirow[t]{3}{*}{ FG } & CLAD & $36.9 \pm 8.0$ & $58.4 \pm 13.6$ & $66.1 \pm 12.2$ & $66.5 \pm 13.9$ \\
\hline & IL & $38.9 \pm 14.3$ & $54.1 \pm 17.8$ & $58.9 \pm 13.7$ & $58.9 \pm 15.2$ \\
\hline & $\mathrm{CDG}$ & $35.8 \pm 9.6$ & $60.7 \pm 13.2$ & $62.9 \pm 13.7$ & $64.3 \pm 10.5$ \\
\hline \multirow[t]{3}{*}{ GG } & CLAD & $37.4 \pm 8.6$ & $57.8 \pm 12.4$ & $62.3 \pm 13.9$ & $65.9 \pm 13.4$ \\
\hline & IL & $39.9 \pm 9.9$ & $53.5 \pm 20.1$ & $56.5 \pm 13.2$ & $58.4 \pm 12.1$ \\
\hline & CDG & $39.5 \pm 8.6$ & $65.9 \pm 14.3$ & $64.8 \pm 13.7$ & $66.1 \pm 12.1$ \\
\hline \multirow[t]{3}{*}{ KG } & CLAD & $36.5 \pm 7.0$ & $62.0 \pm 18.2$ & $60.5 \pm 18.3$ & $60.8 \pm 14.8$ \\
\hline & IL & $42.8 \pm 10.8$ & $50.5 \pm 16.1$ & $52.9 \pm 12.8$ & $52.8 \pm 14.9$ \\
\hline & CDG & $41.9 \pm 8.6$ & $58.3 \pm 15.7$ & $61.8 \pm 13.6$ & $63.5 \pm 14.6$ \\
\hline LSD & & $3.6^{* *}$ & $6.67^{*}$ & $6.9^{*}$ & $7.6^{*}$ \\
\hline
\end{tabular}

*Significant at $P<0.01 ;{ }^{* *}$ significant at $P<0.01$;SD, least significant difference; SD, standard deviation; FG, Fert General Secondary School; GG, Gassaye General Secondary School; KD, Kimer Dengay General Secondary School.

schools compared to IL in which the lowest mean value was recorded in posttest one $(52.2 \pm 15.9)$, posttest two (54.4 \pm 9.8$)$, and posttest three (55.5 \pm 9.1$)$ (Table 2). For this reason, the experimental groups (CDG and CLAD) showed greater improvement in academic achievement. Therefore, the null hypothesis of no significant variation in the average test score of the academic achievement of students' exposed to different teaching methods is rejected. A similar result was reported by Ahmad and Mahmood [24], who explained that there was significantly higher learning gains and positive learning experience in CL $(X=20.17)$ as compared to IT $(X=17.73)$. A few studies $[11,17,25]$ used student achievement division as an experimental treatment in a study involving lowperformance students. They found that the cooperative learning achievement division group scored significantly higher on academic performance than the EFL learners. Swab [26] found that cooperative learning resulted in significantly higher achievement in a college-level computeraided drafting course.

\subsection{The Effect of CL on the Students' Laboratory Proficiency in Biology Subject}

3.2.1. Pretest Scores of the Laboratory Competency by Areas and Teaching Methods. The present study revealed that there was a significant difference $(P<0.05)$ in the pretest

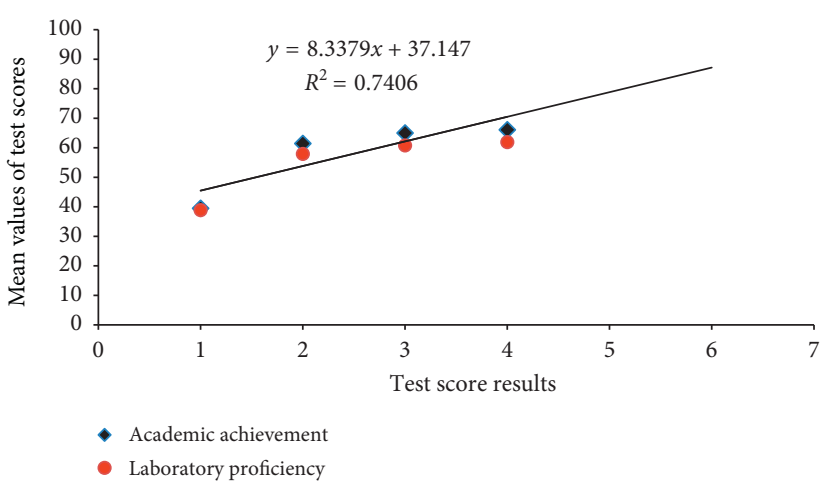

Figure 1: The relationship between the students' academic achievement and laboratory proficiency.

score of the students' laboratory competency by study sites and teaching methods (Table 3). Regardless of the significant difference, numerically the highest mean value of practical skill performance was obtained in Kimer Dengay secondary school $(42.8 \pm 10.8)$ and the lowest mean value $(35.8 \pm 9.6)$ was registered at Fert secondary school (Table 4). This variation in the students' practical skill performance could be attributed to the lack of laboratory equipment and technicians, teachers' commitment, and students' initiation to be engaged in laboratory work. This result well aligned with the study [7] that 
TABle 5: The teachers' and students' view towards CL activities $(n=18 ; 369)$.

\begin{tabular}{|c|c|c|c|c|c|c|c|c|c|}
\hline \multirow{2}{*}{ Characteristics } & \multirow{2}{*}{ Alternatives } & \multicolumn{2}{|c|}{ Frequency } & \multicolumn{2}{|c|}{ Percentage } & \multicolumn{2}{|c|}{ Valid \% } & \multicolumn{2}{|c|}{ Cumulative \% } \\
\hline & & Teachers & Students & Teachers & Students & Teachers & Students & Teachers & Students \\
\hline \multirow{4}{*}{$\begin{array}{l}\text { Desire collaborative work in the school } \\
\text { community }\end{array}$} & Agree & 12 & 219 & 66.67 & 59.3 & 66.67 & 59.3 & 66.67 & 59.3 \\
\hline & Disagree & 5 & 90 & 27.78 & 24.4 & 27.78 & 24.4 & 94.45 & 83.7 \\
\hline & $\begin{array}{c}\text { Have not } \\
\text { realized }\end{array}$ & - & 31 & - & 8.4 & - & 8.4 & - & 92.1 \\
\hline & Undecided & 1 & 29 & 5.55 & 7.9 & 5.55 & 7.9 & 100.0 & 100.0 \\
\hline \multirow{4}{*}{$\begin{array}{l}\text { Implementing cooperative learning on } \\
\text { a regular base }\end{array}$} & Agree & 5 & 89 & 27.78 & 24.1 & 27.78 & 24.1 & 27.78 & 24.1 \\
\hline & Disagree & 8 & 197 & 44.44 & 53.4 & 44.44 & 53.4 & 72.22 & 77.5 \\
\hline & $\begin{array}{c}\text { Have not } \\
\text { realized }\end{array}$ & 3 & 36 & 16.67 & 9.8 & 16.67 & 9.8 & 88.89 & 87.3 \\
\hline & Undecided & 2 & 47 & 11.11 & 12.7 & 11.11 & 12.7 & 100.0 & 100.0 \\
\hline \multirow{4}{*}{$\begin{array}{l}\text { Organized based on interest, } \\
\text { proficiency, and achievement levels }\end{array}$} & Agree & 4 & 43 & 22.22 & 11.6 & 22.22 & 11.6 & 22.22 & 11.6 \\
\hline & Disagree & 9 & 249 & 50 & 67.5 & 50 & 67.5 & 72.22 & 79.1 \\
\hline & $\begin{array}{c}\text { Have not } \\
\text { realized }\end{array}$ & 3 & 29 & 16.67 & 7.9 & 16.67 & 7.9 & 88.82 & 87 \\
\hline & Undecided & 2 & 48 & 11.11 & 13.0 & 11.11 & 13.0 & 100.0 & 100.0 \\
\hline
\end{tabular}

reported a statistically significant difference $(P<0.05)$ in biological skills of students who had no prior knowledge (pretest) of the subject. However, research results of the studies $[6,27]$ contradicted the findings of the present study that explained the absence of significance variation in the students' pretest score on practical competency. Feyzioglu [28] further elucidated that teachers should have a positive attitude towards laboratory use and environment to create impression in students' minds.

3.2.2. Posttest Results on Practical Skill Competency of the Students Exposed to Teaching Methods by Areas. The multivariate analysis indicated that there was a significant difference $(P<0.05)$ in the posttest three result of the students' practical skill competency by areas. However, no significant differences were found in the posttest one and two results of the students' practical skill competency (Table 3). Nonetheless, numerically there was a trend in increasing the students' score results within the successive tests. Thus, the higher average values were recorded in CDG $(65.9 \pm 14.3)$ of posttest one and CLAD of posttest two $(66.1 \pm 12.2)$ and posttest three $(66.5 \pm 13.9)$, respectively, as compared to the IL method (Table 4). As a result, the null hypothesis that explains that there is no significant difference in posttest scores of the laboratory competency exposed by different teaching methods is rejected. This finding is consistent with the result of Orora et al. [10], who reported that there was no significant difference $(t=2.87$, $P>0.05)$ in the pre- and posttest results of the students' academic achievement using CEL strategy and IL in biology lessons. However, a higher mean score result was obtained via CEL compared to the IL. Significantly higher result was also achieved in successful students by using high level of laboratory skills in chemistry course [28]. Hofstein and Mamlok-Naaman [29] further reviewed and reported that performed laboratory activities based on interest and achievement levels enhance students' science process and problem-solving skills.
3.3. The Relationship between the Students' Academic Achievement and Laboratory Proficiency in Biology Subject. The result obtained from the correlation analysis revealed that there was substantial relationship between the laboratory proficiency and academic performance in biology influenced by different teaching methods and study sites. This is indicated by the students' test score results that showed a positive increment after the delivery of the pretests $(39.466 ; 38.87)$ for both the academic and laboratory performances, respectively (Figure 1). Even though the two learning performances were significantly correlated, the highest average values were registered on the students' academic achievement in the entire results of the posttest one (61.434), posttest two (65.0), and posttest three (66.07) as compared to their laboratory competency (57.93, 60.77, and 61.92) in posttests, respectively (Figure 1). The lower mean values in laboratory competency could be attributed to the lack of proper laboratory equipment and chemicals and the students' acquaintances with the laboratory tests. This is in line with the research findings $[30,31]$, which stated laboratory classes with well-administered experiments and appropriate methods improve the students' skills like scientific thinking, observation, creating thinking, and problem-solving ability.

\subsection{The Overall Perception of the Sampled Respondents to CL Strategies}

3.4.1. Teachers' and Students' Propensity for the Effective Implementation of CL. The results of the questionnaire survey revealed that $12(66.67 \%)$ teachers and $219(59.3 \%)$ students of the sample give better credence to collaborative work than working independently (Table 5). This implies that these respondents understood the significance of CL as a widely accepted approach of teaching that encourages interactive learning. This concedes with the research findings of the study [15] that showed that teachers' positive belief on CL activities could be attributed to the 


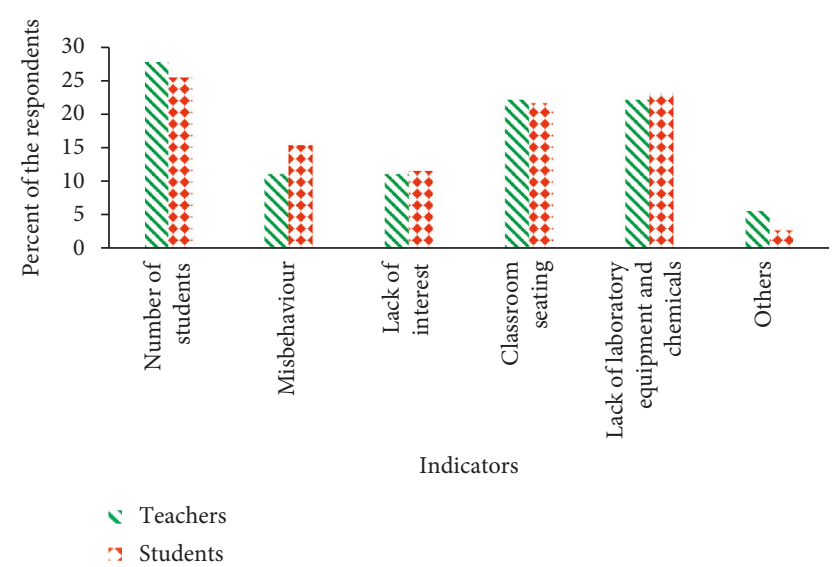

FIGURE 2: The factors affecting the successive implementation of CL activities in the schools.

prepedagogical and in-service training on CL. Conversely, $5(27.78 \%)$ of the sampled respondent teachers and 90 (24.4\%) students showed preference to work independently (Table 4). Brown et al. [32] point out that the traditional method may attribute to the achievement gap, while CL focuses on interdependence that promotes intellectual growth and competency of learners. Furthermore, $5(27.78 \%)$ and $89(24.1 \%)$ of the sampled individuals favor CL and thus executed it regularly in their classrooms (Table 5). As noted by Gilliam [33], CL is a viable and effective instructional method because it guarantees the building of higher level thinking skills and academic achievement. From the total respondents 4 teachers $(22.22 \%)$ and 43 students (11.6\%) percieved that, $\mathrm{CL}$ is better when students are organized based on their interest and academic achievents (Table 5). Similar findings were reported by Fiszer [30], who explained the significant learning gain when students are organized by their level of interest and learning performance.

3.4.2. Factors That Impede the Effective Execution of CL. A number of factors affect the successive implementation of $\mathrm{CL}$ activities during the teaching-learning process. Thus, 5 (27.8\%) of the sampled teachers and 94 (25.5\%) students discretely perceived that the number of students or classroom size is the major factor that setbacks CL activities in the selected schools. On the other hand, $4(22.2 \%)$ of the teachers and 85 (23.1) students considered the shortage of biological materials and chemicals as a major factor for CL (Figure 2). Surprisingly, 1 (5.6\%) of the respondent teachers and $10(2.7 \%)$ students found that some factors like lack of providing enthusiastic approaches significantly influenced the successive execution of CL in the study areas (Figure 2). This perception of the sample respondents is in agreement with the findings of Anto et al. [15], who revealed that classroom size, lack of proper training on CL, lack of pedagogical knowledge and skill, and lack of supportive materials are the substantial factors that are encountered on CL implementation.

\section{Conclusions}

Based on the research findings, the following conclusions are met: (1) considerable increments in the biology achievement and laboratory competence were seen in students exposed to CLAD through successive score tests, followed by $\mathrm{CDG}$, and lower performance was registered by IL; (2) significant relationship in the students' academic achievement and laboratory proficiency was observed through continual tests; and (3) the sample respondents perceived that CL methods, especially the CLAD, provided higher learning gains in biology. However, some factors affect the successive implementation of the methods. Therefore, to foster the students' entire competency, teachers can implement innovative ways of teaching like CLAD and CDG in their actual classroom, encourage to develop positive belief, and create conducive environment for CL.

\section{Appendix}

\section{Questionnaire on the Overall Perception of the Teachers and the Students towards CL Approaches}

Dear respondents, this questionnaire is one of the research tools developed to gather information on the "Impact of Cooperative Learning Approaches on Students' Academic Achievement and Laboratory Proficiency in Biology Subject in Selected Rural Schools, Ethiopia." The information apprehended was used to conceive the perception of teachers and students towards the teaching approaches and the factors that hamper cooperative learning approaches and to provide possible suggestion based on the findings of the research. The questionnaire is divided into three parts in order to collect information related to cooperative learning approaches. Thus, you are kindly requested to furnish your honest and valuable responses to fill in this questionnaire. Your candid response is highly relevant for the study, and it will be used only for academic purposes.

Please note that the research notion is used to evaluate the effectiveness of teaching methods, which are the cooperative learning discussion group (one top achiever student leads the other five different academic performance levels of students), cooperative learning achievement division or CLAD (one top achiever student directs the other five with the same level of performance (top achievers) and middle achievers and lower achievers are also arranged separately based on the previous results collected from the schools registrar), and the individual learning (lecturing) methods. 


\section{Part I: Personal Information}

Name of school

Sex: Male $\square \quad$ Female $\square$

Level of education
Age

Your job title and experience

\section{Part II: About the effectiveness of cooperative learning approaches}

Put your judgment using a mark of " $\sqrt{ }$ " under the indicators that correspond to the key characteristics.

\begin{tabular}{|c|c|c|c|c|c|c|}
\hline \multirow[b]{2}{*}{ Indicators } & \multirow[b]{2}{*}{ Number } & \multirow[b]{2}{*}{ Characteristics } & \multicolumn{4}{|c|}{ Level of proficiency } \\
\hline & & & $\begin{array}{l}\text { Agree } \\
(1)\end{array}$ & $\begin{array}{l}\text { Disagree } \\
(2)\end{array}$ & $\begin{array}{l}\text { I do not } \\
\text { realize }(3)\end{array}$ & $\begin{array}{c}\text { Undecided } \\
(4)\end{array}$ \\
\hline \multirow{9}{*}{ CL acuity } & 1 & $\begin{array}{l}\text { Collaborating to work with each other in the school } \\
\text { community }\end{array}$ & & & & \\
\hline & 2 & $\begin{array}{l}\text { Teaching the students cooperatively rather than } \\
\text { conventional lecturing }\end{array}$ & & & & \\
\hline & 3 & $\begin{array}{c}\text { Implementing cooperative learning approaches on } \\
\text { a regular basis }\end{array}$ & & & & \\
\hline & 4 & $\begin{array}{c}\text { Organizing the students to work on the basis of interest } \\
\text { and academic achievement level }\end{array}$ & & & & \\
\hline & 5 & $\begin{array}{c}\text { Grouping students regarding achievement division } \\
\text { (higher achievers organized alone, and middle and } \\
\text { lower achievers distinctly) }\end{array}$ & & & & \\
\hline & 6 & $\begin{array}{l}\text { Surveying their levels and scaling up their achievement } \\
\text { division after subsequent measurement through test or } \\
\text { other mechanisms }\end{array}$ & & & & \\
\hline & 7 & $\begin{array}{l}\text { Sharing experience with peers on the consecutive } \\
\text { execution of cooperative learning approaches }\end{array}$ & & & & \\
\hline & 8 & $\begin{array}{l}\text { Developing ways to enhance all-round participation of } \\
\text { the students during cooperative learning approaches }\end{array}$ & & & & \\
\hline & 9 & $\begin{array}{c}\text { Providing appropriate reinforcement and initiation to } \\
\text { do things in group }\end{array}$ & & & & \\
\hline \multirow{7}{*}{$\begin{array}{l}\text { Lesson } \\
\text { evaluation }\end{array}$} & 10 & $\begin{array}{l}\text { Intending the annual plan in accordance with } \\
\text { cooperative learning activity }\end{array}$ & & & & \\
\hline & 11 & $\begin{array}{c}\text { Integrating cooperative learning activities with the } \\
\text { lesson objectives }\end{array}$ & & & & \\
\hline & 12 & $\begin{array}{l}\text { Allocating the appropriate depth of the lesson for } \\
\text { cooperative learning in accordance with their } \\
\text { achievement division }\end{array}$ & & & & \\
\hline & 13 & $\begin{array}{l}\text { Dividing the lesson into small and easily digestible } \\
\text { pieces for the discussion (explain prerequisite facts and } \\
\text { reteaching if necessary) }\end{array}$ & & & & \\
\hline & 14 & $\begin{array}{l}\text { Maintaining proper time for discussion and allowing } \\
\text { them to reflect their ideas at the time of discussion }\end{array}$ & & & & \\
\hline & 15 & $\begin{array}{c}\text { Providing review or stabilizing the lesson following } \\
\text { students' discussion }\end{array}$ & & & & \\
\hline & 16 & $\begin{array}{l}\text { Evaluating students' attitude and understanding } \\
\text { frequently following the cooperative learning activities } \\
\text { (by giving questions and group and individual works) }\end{array}$ & & & & \\
\hline \multirow{5}{*}{$\begin{array}{l}\text { School } \\
\text { environment }\end{array}$} & 17 & Arranging proper placement for the students during CL & & & & \\
\hline & 18 & $\begin{array}{l}\text { Creating conducive environment for cooperative } \\
\text { learning }\end{array}$ & & & & \\
\hline & 19 & $\begin{array}{l}\text { Monitoring the behaviour of the students when in } \\
\text { discussion and advising those disrupting the class }\end{array}$ & & & & \\
\hline & 20 & $\begin{array}{c}\text { Attending (controlling) the students regularly using } \\
\text { various monitoring mechanisms during cooperative } \\
\text { work }\end{array}$ & & & & \\
\hline & 21 & $\begin{array}{l}\text { Conducting case study or action research about the } \\
\text { effectiveness, factors, possible solution, and on school } \\
\text { environment for cooperative learning activities }\end{array}$ & & & & \\
\hline
\end{tabular}




\section{Part III: Open-ended questions}

(1) How do you see the students' keenness to participate in the CL approaches?

(2) Have you grouped students based on their interests and academic performance? If no, what kind of problems hinders you to do so?

(3) In your view, what are the factors that hamper or promote the effective accomplishment of cooperative learning approaches in your school environment?

(4) What possible solution did you provide for the problem facing you up on the successive implementation of cooperative learning approaches?

(5) Provide your overall comments and suggestions on the relevance of cooperative learning regarding achievement levels for students' academic performance and laboratory competency.

Thank you in Advance!!!

\section{Conflicts of Interest}

The authors declare that there are no conflicts of interest.

\section{Acknowledgments}

The authors thank the educational officials of the South Gondar and Amhara Regional Bureau of Education for providing valuable comments and suggestions to strengthen the paper. The authors are very grateful to the teachers and students involved in this research. The authors also thank the school principals and supervisors for their encouragement and for facilitating things while conducting the research.

\section{References}

[1] I. Amosa, M. James, and C. Olubode, "Effectiveness of videobased cooperative learning strategy on high, medium and low academic achievers," The African Symposium, An Online Journal of the African Educational Research Network, vol. 13, no. 2, pp. 77-85, 2013.

[2] S. Wang, W. Pei, and Y. Cheung, "An improved competitive and cooperative learning approach for data clustering," in Proceedings of the International Conference on Computational Intelligence and Security, (CIS 2007), pp. 15-19, Harbin, Heilongjiang, China, December 2007.

[3] U. Martins and N. Fidelia, "Co-operative learning approach and students achievement in sociology," An International Multi-Disciplinary Journal, vol. 3, no. 3, pp. 388-398, 2009.

[4] D. W. Johnson, R. T. Johnson, and K. Smith, "The state of cooperative learning in post-secondary and professional settings," Educational Psychology Review, vol. 19, pp. 15-29, 2007.

[5] B. Karen, "Biology and society, a new way to teach tertiary science to non-science students," Journal of Education, vol. 1, no. 2, p. 12, 2008.

[6] E. Kaunang, "The effect of cooperative learning model and belief about science on the biology learning achievement by controlling the initial ability of students experiment study on eighth grade students of public junior high school in Minahasa," Journal of Education and Practice, vol. 5, no. 7, pp. 5-8, 2014.

[7] D. N. Muraya and G. Kimamo, "Effects of cooperative learning approach on biology mean achievement scores of secondary school students in Machakos District Kenya," Journal of Educational Research and Reviews, vol. 6, no. 12, pp. 726-745, 2011.

[8] FAWE, "Teachers training qualification and working conditions," Report no. 8, pp. 7-12, Forum for African Women Educationalists, Nairobi, Kenya, 1998.

[9] J. Otuka and B. Uzoechi, History and Philosophy of Science, Onavi Printing \& Publishing Co. Nigeria Ltd., Keffi, Nigeria, 2009.

[10] W. Orora, F. N. Keraro, and S. W. Wachanga, "Effects of cooperative e-learning teaching strategy on students' achievement in secondary school biology in Nakuru County, Kenya," Sky Journal of Education Research, vol. 2, no. 1, pp. 1-9, 2014.

[11] D. Glomo-Narzoles, "Student team achievement division (STAD), its effect on the academic performance of EFL learners," American Research Journal of English and Literature, vol. 1, no. 4, pp. 1-7, 2015.

[12] M. Robyn and F. Adrian, Co-Operative Learning, the Social and Intellectual Outcomes of Learning in Groups, Taylor and Francis e-library, New York, NY, USA, 1st edition, 2003. 
[13] M. R. Gillies and M. Boyle, "Teachers' reflections on cooperative learning, issues of implementation," Teaching and Teacher Education, vol. 26, no. 4, pp. 933-940, 2010.

[14] N. M. Webb and A. Mastergeorge, "Promoting effective helping in peer-directed groups," International Journal of Educational Research, vol. 39, no. 1-2, pp. 73-97, 2003.

[15] A. G. Anto, F. Coenders, and J. Voogt, "Assessing the current implementation of communicative language teaching in Ethiopia Universities in reference to Arbaminch University Ethiopia," Journal of Educational Development International, vol. 16, no. 1, pp. 51-69, 2012.

[16] B. Gokkurt, S. Dundar, Y. Soylu, and L. Akgun, "The effects of learning together techniques which is based on cooperative learning on students' achievement in Mathematics class," Procedia-Social and Behavioral Sciences, vol. 46, pp. 34313434, 2012.

[17] T. Liang, "Implementing cooperative learning in EFL teaching: process and effects," Ph.D. dissertation, National Taiwan University, Taipei, Taiwan, 2002.

[18] A. Yusuf, "Effects of cooperative and competitive instructional strategies on junior secondary school students' performance in social studies," Ph.D. dissertation, Ilorin, Nigeria, 2004.

[19] B. Adegoke, "Effect of multimedia instruction on senior secondary school students' achievement in physics," European Journal of Educational Studies, vol. 3, no. 3, pp. 537-541, 2011.

[20] P. A. Okebukola, "The relative effectiveness of cooperative and competitive interaction techniques in strengthening students' performance in science class," Science Education, vol. 69, no. 4, pp. 501-509, 1985.

[21] R. M. Mattingly and R. L. VanSickle, "Cooperative learning and achievement in social studies," Social Education, vol. 55, no. 6, pp. 392-385, 1991.

[22] E. Slavin, Cooperative Learning Theory, Research and Practice, Allyn \& Bacon, Boston, MA, USA, 1995.

[23] C. Kothari, "Sample size and sampling procedure," p. 218, 2006, http://abere.us/FILES/kothari-sample-size-determination.

[24] Z. Ahmad and N. Mahmood, "Effects of cooperative learning vs. traditional instruction on prospective teachers learning experience and achievement," Journal of Faculty of Educational Sciences, vol. 43, no. 1, pp. 151-164, 2010.

[25] D. O. Fakeye, "Students' personal variables as correlates of academic achievement in english as a second language in Nigeria," Journal of Social Sciences, vol. 22, no. 3, pp. 205-211, 2010.

[26] G. Swab, "The effects of cooperative and individualistic learning structures on achievement in a college-level computer-aided drafting course," Ph.D. dissertation, Virginia Polytechnic Institute and State University, Blacksburg, VA, USA, 2012.

[27] K. Keter, H. Barchok, and J. Ng'eno, "Effects of cooperative mastery learning approach on students' motivation to learn chemistry by gender," Journal of Education and Practice, vol. 5, no. 8, pp. 92-97, 2014.

[28] B. Feyzioglu, "An investigation of the relationship between science processes skills with efficient laboratory use and science achievement in chemistry education," Journal of Turkish Science Education, vol. 6, no. 3, pp. 115-132, 2009.

[29] A. Hofstein and R. Mamlok-Naaman, "The laboratory in science education, the state of the art," Chemistry Education Research and Practice, vol. 8, no. 2, pp. 105-107, 2007.

[30] E. P. Fiszer, How Teachers Learn Best, An Ongoing Professional Development Model, Scarecrows Education, Lanham, MD, USA, 2004.

[31] A. Hofstein and V. N. Lunetta, "The laboratory in science education, foundations the twenty first century," Science Education, vol. 88, no. 1, pp. 28-54, 2003.
[32] N. Brown, E. Oke, and D. Brown, Curriculum and Instruction an Introduction to Methods of Teaching, Macmillan Publishers Limited, Kuala Lumpur, Malaysia, 2nd edition, 1982.

[33] H. Gilliam, "The impact of cooperative learning and course learning environment factors on learning outcomes and overall excellence in the community college classroom," Ph.D. dissertation, University of North Carolina State, Raleigh, NC, USA, 2002. 


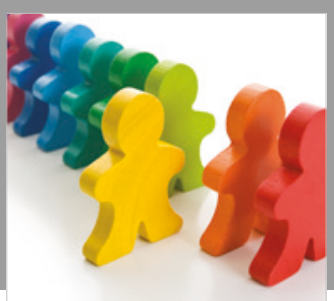

Autism

Research and Treatment
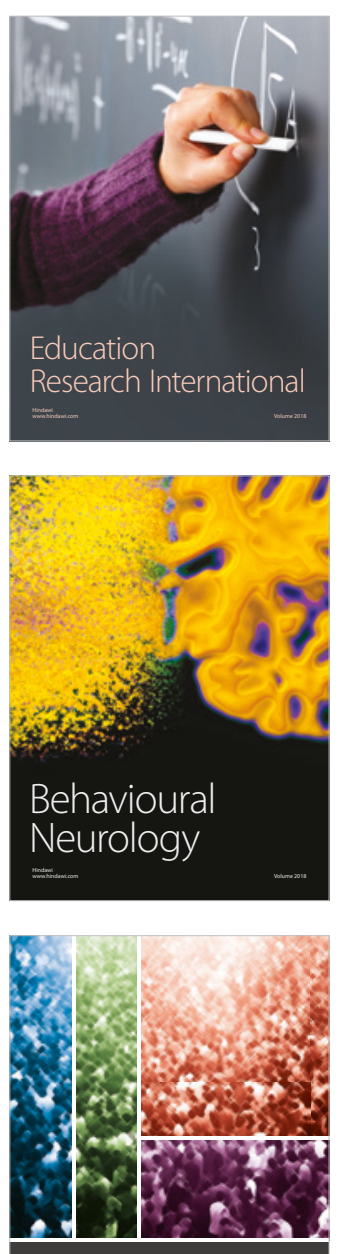

International Journal of

Population Research

$\underline{-m}$

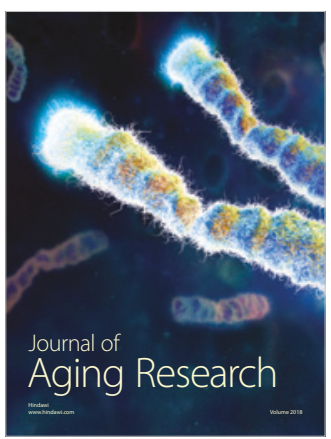

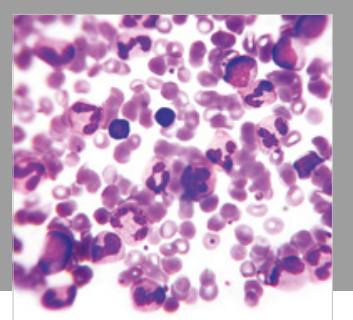

Pathology

Research International$$
=
$$

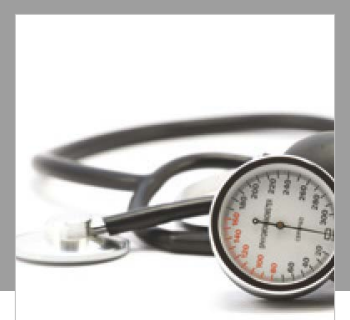

Nursing

Research and Practice

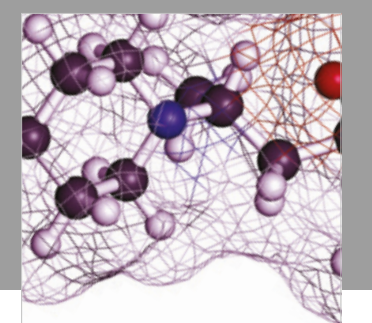

Pain

Research and Management

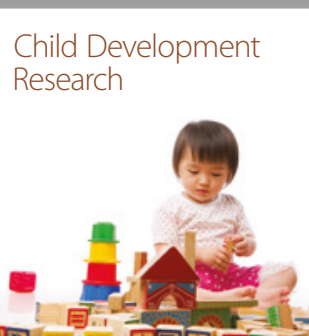

बाD

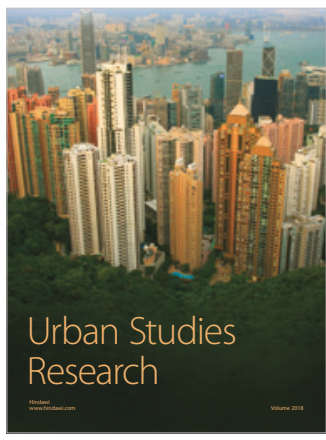

\section{Hindawi}

Submit your manuscripts at

www.hindawi.com
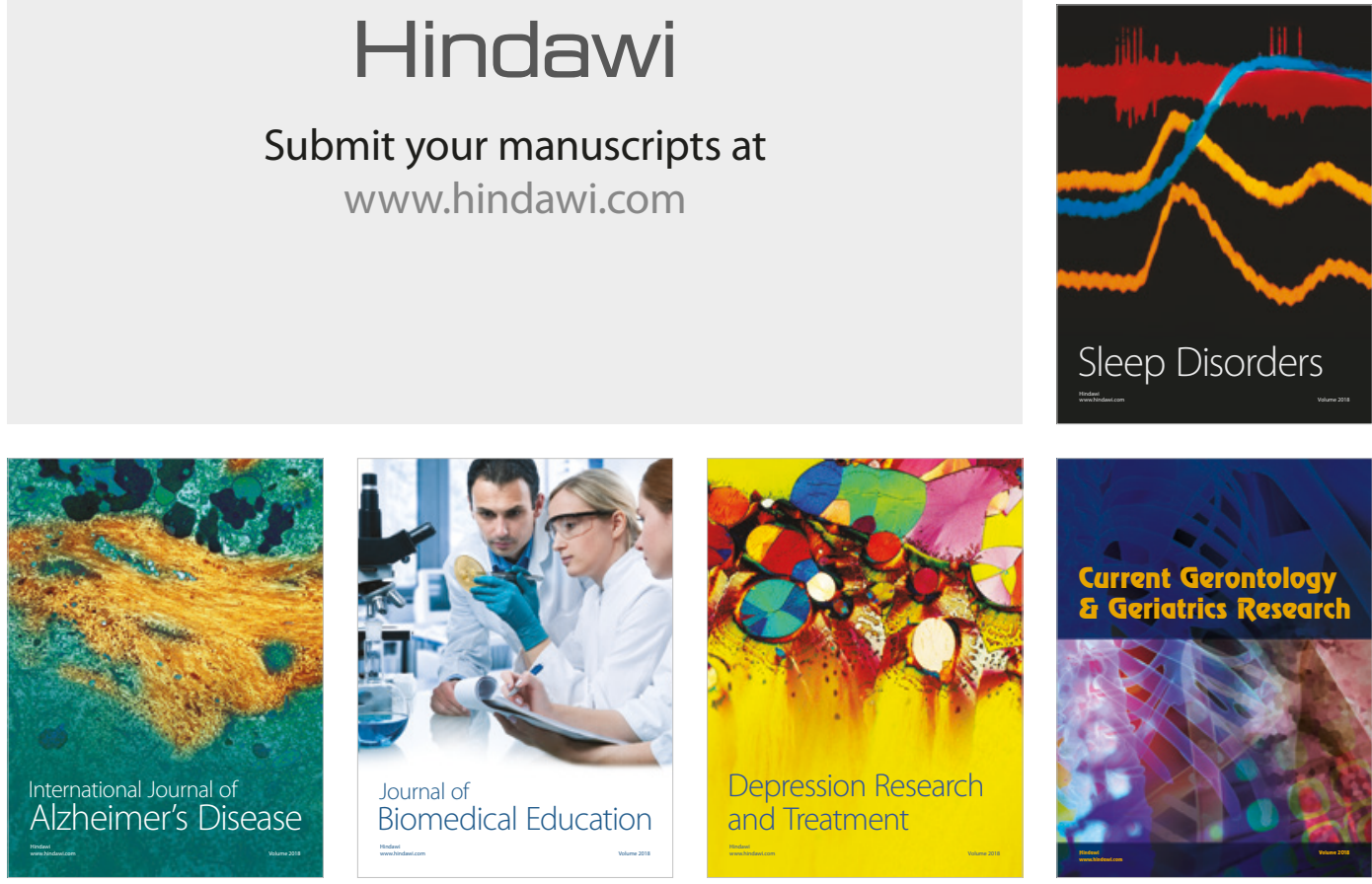

Journal of

Biomedical Education

$=$

smman

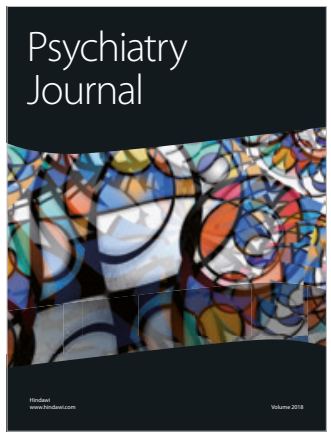

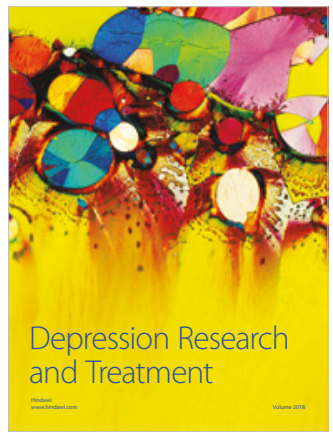
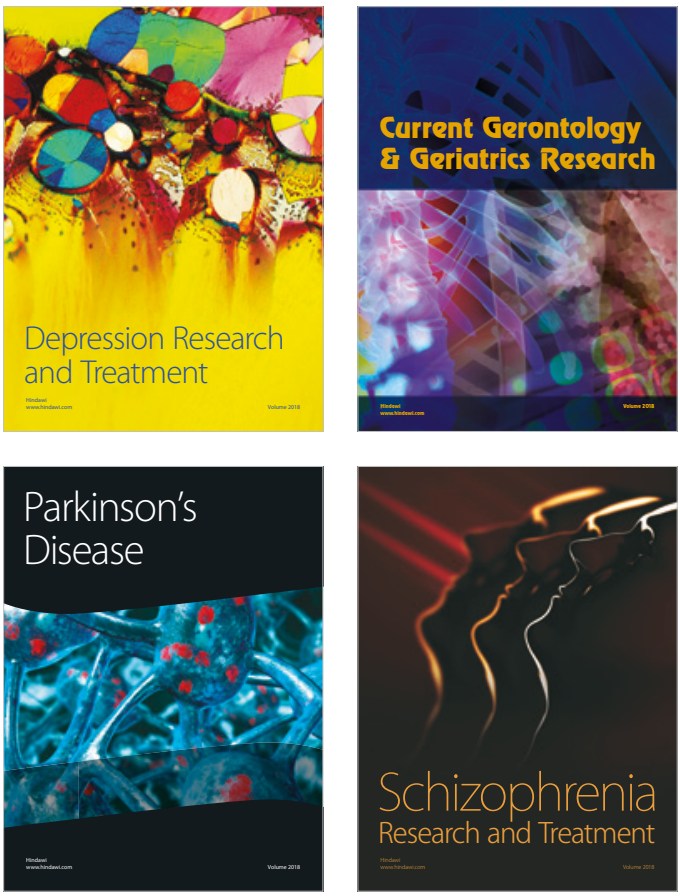